\title{
Responses of Four Types of Winter Wheat to Fenoxaprop-p-ethyl
}

\author{
Kimberly D. Belfry*, Peter H. Sikkema \\ Ridgetown Campus, University of Guelph, Ridgetown, Canada \\ Email: ${ }^{*}$ kimberly.belfry@gmail.com \\ Received 18 January 2015; accepted 2 February 2015; published 6 February 2015 \\ Copyright (C) 2015 by authors and Scientific Research Publishing Inc. \\ This work is licensed under the Creative Commons Attribution International License (CC BY). \\ http://creativecommons.org/licenses/by/4.0/ \\ (c) (i) Open Access
}

\begin{abstract}
Fenoxaprop-p-ethyl is a selective grass herbicide that if registered will provide winter wheat growers with an additional weed control option. Field experiments were established in the fall of 2011, 2012 and 2013 at Ridgetown and Exeter, Ontario, to determine the sensitivity of four market classes of winter wheat [Soft white winter wheat (SWWW), soft red winter wheat (SRWW), hard white winter wheat (HWWW) and hard red winter wheat (HRWW)] to 1X and 2X fenoxaprop-p-ethyl/safener at early-(EPOST) or late-post emergence (LPOST) application timings. Fenoxaprop-p-ethyl/safener applied LPOST at $1 \mathrm{X}$ and $2 \mathrm{X}$ the manufacturer's proposed label rate caused $4 \%$ and $5 \%$ injury 1 week after application (WAA), respectively. The injury observed was transient with 1\% injury 2 WAA. Winter wheat height ranged from 91 to 95,76 to 77,76 to 79 and 90 to $93 \mathrm{~cm}$ while grain yield was 6.2 to $6.4,6.1$ to $7.1,5.5$ to 5.8 and 5.6 to 6.2 thha $^{-1}$ for SWWW, SRWW, HRWW and HRWW, respectively. Exeter sites were not affected by fenoxaprop-p-ethyl/ safener treatment. At Ridgetown and Exeter, no market class-specific response was identified for the cultivars evaluated. Based on this study, fenoxaprop-p-ethyl/safener has the potential to cause only minor and transient injury in winter wheat that will not decrease yield. Furthermore, this research supports the registration of fenoxaprop-p-ethyl/safener for spring POST application in winter wheat in Ontario.
\end{abstract}

\section{Keywords}

Fenoxaprop-p-ethyl, Tolerance, Winter Wheat

\section{Introduction}

With over 700,000 hectares seeded annually, winter wheat (Triticum aestivum L.) is one of Canada’s most im-

${ }^{*}$ Corresponding author. 
portant cereal crops [1]. Canadian production occurs largely in Ontario, where winter wheat is ranked third highest as the province's most cultivated field crop, by area [2]. Ontario produces on average two million metric tonnes per year with a farm gate value up to \$500 million [2]. Many growers choose to grow winter wheat because of its excellent yield potential, profitability and the flexibility in time management that it provides during busy parts of the growing season. Winter wheat is seeded in the fall in narrowly spaced rows that enable this competitive crop to suppress weeds, while its fibrous roots help to maintain soil structure and prevent erosion due to wind and water [3]. This sustainable crop fits well into reduced- and no-till systems and has the potential to produce yields that are upwards of 30\% higher than spring wheat if managed properly [4]. Given the potential of this fall-seeded cereal, market class and cultivar selection are important considerations when trying to maximize winter survival, quality, yield and profitability.

More than 100 cultivars of winter wheat are available that may be grouped into four market classes of wheat; soft white winter wheat (SWWW), soft red winter wheat (SRWW), hard white winter wheat (HWWW) and hard red winter wheat (HRWW) [1]. Winter wheat may be processed into flour, cereal food and feed, or bread and bakery products; however, protein content, kernel harness and dough properties determine the end use for each market class and cultivar. When selecting a winter wheat cultivar it is important to not only consider end use, but to consider traits including cultivar resistance to disease, lodging and overall winter hardiness that will best maximize yield potential [3].

Differential herbicide tolerance across market class may further impact winter wheat yield and has been reported in the literature. Reference [5] assessed crop tolerance of SWWW, SRWW and HRWW to various post emergence (POST) spring-applied herbicides and found that SWWW and SRWW were most susceptible to injury from dicamba plus MCPA and mecoprop. Reference [6] evaluated winter wheat tolerance to mesosulfuron-methyl and reported similar injury for soft and hard cultivars but found that the soft cultivars tended to be more resilient and recovered better. Moreover, SRWW sensitivity to dicamba has also been reported [7] [8]. As cultivar choice has the potential to affect crop tolerance, one must consider the implications when selecting a suitable herbicide.

First discovered in the early 1970s, fenoxaprop-p-ethyl is a Group 1 herbicide that belongs to aryloxyphenoxypropionate family used for selective control of annual grasses [9]. Fenoxaprop-p-ethyl blocks de novo fatty acid biosynthesis in sensitive plants via inhibition of acetyl co-A carboxylase; an enzyme that facilitates the ATP-dependent carboxylation of acetyl-coA to malonyl-coA [10] [11]. Fenoxaprop-p-ethyl may be applied POST in spring wheat or barley (Hordeum vulgare L.) and confers selectivity via metabolism by tolerant species [12]. Sensitive weeds include barnyard grass [Echinachloacrusgali (L.) Beav.], green foxtail [Setaria viridis (L.) Beauv.], yellow foxtail [Setaria glauca (L.) Beauv.] and wild oat (Avena fatua L.) [12]. Application of fenoxaprop-p-ethyl without a safening agent has the potential to cause severe injury in spring cereal crops, therefore, a pre-packaged formulation containing mefenpyr-diethyl is available to growers to limit damage [13]. Mefenpyr-diethyl is a foliar acting safener that improves crop tolerance through increased metabolism and detoxification of herbicidal ingredients [14].

In Ontario, fenoxaprop-p-ethyl/safener is not currently registered for use winter wheat [12]. Information regarding the safety of fenoxaprop-p-ethyl/safener on winter wheat under environmental conditions in Ontario is limiting. If there is an adequate margin of crop safety for fenoxaprop-p-ethyl/safener applied POST in winter wheat, registration would provide growers with an additional option for grass weed control. The objective of this study was to assess the tolerance of SWWW, SRWW, HWWW and HRWW to fenoxaprop-p-ethyl/safener applied at $1 \mathrm{X}$ and $2 \mathrm{X}$ rates at early- and late-POST application timings, under Ontario growing conditions.

\section{Materials and Methods}

\subsection{Study Establishment}

Six field trials were conducted in Ontario, to evaluate the tolerance of four market classes of winter wheat to fenoxaprop-p-ethyl/safener. Three experiments were conducted each at the University of Guelph, Ridgetown Campus $\left(42^{\circ} 26^{\prime} \mathrm{N}, 81^{\circ} 53^{\prime} \mathrm{W}\right)$ and the Huron Research Station near Exeter $\left(43^{\circ} 19^{\prime} \mathrm{N}, 81^{\circ} 30^{\prime} \mathrm{W}\right)$; experiments were established in the fall of 2011, 2012 and 2013. Seedbed preparation consisted of tillage using a moldboard plow flowed by cultivation to ensure a level seedbed. Location, year and soil characteristics are summarized in Table 1.

Experiments were established as a two-way factorial with four replications. Factor one was winter wheat market class [Soft white winter wheat (SWWW), soft red winter wheat (SRWW), hard white winter wheat 
Table 1. Location, year, soil charactersitics, and EPOST and LPOST herbicide application dates for fenoxaprop-p-ethyl winter wheat tolerance studies conducted in Ontario, Canada ${ }^{\mathrm{a}}$.

\begin{tabular}{|c|c|c|c|c|c|c|c|c|c|c|}
\hline \multirow{2}{*}{ Site } & \multirow{2}{*}{$\begin{array}{c}\text { Year } \\
\text { planted }\end{array}$} & \multirow{2}{*}{ Location } & \multirow{2}{*}{ Soil texture } & Sand & Silt & Clay & $\mathrm{OM}$ & \multirow{2}{*}{$\mathrm{pH}$} & \multirow{2}{*}{ EPOST date } & \multirow{2}{*}{ LPOST date } \\
\hline & & & & \multicolumn{4}{|c|}{ (\%) } & & & \\
\hline $\mathrm{S} 1$ & 2011 & Ridgetown & Sandy loam & 54 & 27 & 19 & 5.6 & 6.4 & 04 May 2012 & 11 May 2012 \\
\hline $\mathrm{S} 2$ & 2011 & Exeter & Loam & 35 & 39 & 26 & 3.2 & 8.0 & 25 April 2012 & 09 May 2012 \\
\hline S3 & 2012 & Ridgetown & Loam & 41 & 34 & 25 & 6.5 & 6.7 & 26 April 2013 & 09 May 2013 \\
\hline $\mathrm{S} 4$ & 2012 & Exeter & Loam & 37 & 37 & 26 & 3.2 & 7.7 & 26 April 2013 & 09 May 2013 \\
\hline S5 & 2013 & Ridgetown & Sandy clay loam & 48 & 28 & 24 & 6.7 & 6.6 & 24 April 2014 & 11 May 2014 \\
\hline S6 & 2013 & Exeter & Clay loam & 35 & 43 & 22 & 3.6 & 7.6 & 05 May 2014 & 19 May 2014 \\
\hline
\end{tabular}

${ }^{a}$ Abbreviations: EPOST, early postemergence; LPOST, late postemergence.

(HWWW) and hard red winter wheat (HRWW)] and factor two was fenoxaprop-p-ethyl/safener treatment (untreated control, $1 \mathrm{X}$ early POST, $2 \mathrm{X}$ early POST, $1 \mathrm{X}$ late POST and 2X late POST). Winter wheat cultivars "Ava" (SWWW), "Pioneer 25R47" (SRWW), "White bear" (HWWW) and "Wentworth" (HRWW) were seeded at a depth of $4 \mathrm{~cm}$ using a double disc drill at $150 \mathrm{~kg} \cdot \mathrm{ha}^{-1}$ with $19 \mathrm{~cm}$ row spacing. Plots measured 2 by $10 \mathrm{~m}$ for Ridgetown and 2 by $11 \mathrm{~m}$ for Exeter sites. Winter wheat was seeded late September to early November. As per wheat management practices in Ontario, nitrogen was applied in the spring following seeding at $110 \mathrm{~kg} \cdot \mathrm{N} \cdot \mathrm{ha}{ }^{-1}$; phosphorus and potassium requirements were determined based on soil P-K levels using rates outlined by the Ontario Ministry of Agriculture, Food and Rural Affairs [15]. Fenoxaprop-p-ethyl/safener was applied at 92 (1X) or $184 \mathrm{~g} \cdot \mathrm{ai} \cdot \mathrm{ha}^{-1}(2 \mathrm{X})$ at either early (EPOST) or late (LPOST) postemergence timing; dates of herbicide application are listed in Table 1 . Herbicide treatments were applied using a $\mathrm{CO}_{2}$-pressurized backpack sprayer calibrated to deliver $200 \mathrm{~L}$ aqueous solution per ha. Boom length was $1.5 \mathrm{~m}$ with four ultra-low drift nozzles (ULD 120-02; Hypro, New Brighton, MN) spaced $50 \mathrm{~cm}$ apart. To avoid the confounding effects of weed competition, plots were kept free of weeds by hoeing and hand weeding as required throughout the growing season.

\subsection{Data Collection}

Winter wheat injury was visually assessed on a scale of $0 \%$ (no injury present) to $100 \%$ (complete plant death) at 1, 2, 4 and 8 weeks after herbicide application (WAA). Wheat height was determined for ten random plants per plot at 8 WAA and averaged. Wheat head distortion was visually assessed on a scale of $0 \%$ (no distortion present) to $100 \%$ (complete distortion) just prior to harvest. Winter wheat was harvested at maturity with a small plot combine and moisture and weight were recorded; based on which yields were adjusted to $14 \%$ moisture.

\subsection{Statistical Analysis}

Data were analyzed as a 2-way factorial using PROC MIXED in SAS (Ver 9.3 Cary, NC). Fixed effects included the two treatment factors, winter wheat market class and herbicide treatment, as well as their interaction; random effects included year-location combinations (environment), interactions between environment and the fixed effects, and replicate nested within environment. Significance of fixed effects was tested using $F$ tests and random effects were tested using a $\mathrm{Z}$ test of the variance estimate. The UNIVARIATE procedure was used to test data for normality and homogeneity of variance. To satisfy the assumptions of the variance analyses, Exeter injury 1 WAA was square root-transformed and Ridgetown wheat height was arcsine-transformed. For all injury ratings, the non treated control (assigned a value of zero) was excluded from the analysis. However, all values were compared independently to zero to evaluate treatment differences with the non treated control. Treatment comparisons were made using Fisher's Protected Least Significant Difference test at a level of $P<0.05$. All data compared on the transformed scale was converted back to its respective original scale prior to presentation of results.

\section{Results and Discussion}

Ridgetown and Exeter locations were analyzed separately due to a significant environment by main effect (herbicide or winter wheat market class) interaction. No significant environment by main effect interaction was present within location, thus all site years were pooled individually for Ridgetown and Exeter. Except at S2, no 
winter wheat injury was present 4 WAA (Table 1). S2 injury ranged from $2 \%$ to $5 \%$ and occurred only for $2 \mathrm{X}$ LPOST application timing (data not shown). No injury was observed 8 WAA (data not shown). Additionally, no significant wheat head distortion was present prior to winter wheat harvest (data not shown).

For Ridgetown sites, analysis of the main effects determined winter wheat market class to be non significant for injury (1 and 2 WAA) and moisture (Table 2). On the contrary, crop height and grain yield were found to be significant for winter wheat market class. Winter wheat height was greatest for SWWW $(95 \mathrm{~cm})$ and HRWW $(93 \mathrm{~cm})$ cultivars, whereas SRWW and HWWW cultivars were $76 \mathrm{~cm}$ in height. SWWW, SRWW, HWWW and HRWW yielded 6.4, 7.1, 5.8 and $6.2 \mathrm{t} \cdot \mathrm{ha}^{-1}$, respectively.

Unlike winter wheat market class, fenoxaprop-p-ethyl/safener treatment at Ridgetown was significant solely for injury 1 and 2 WAA (Table 2). At 1 WAA, injury for both $1 \mathrm{X}$ and 2X EPOST applications did not differ from the untreated control. However, LPOST applications caused injury of $4 \%$ and $5 \%$ for $1 \mathrm{X}$ and $2 \mathrm{X}$ rates, respectively. The injury was transient with only $1 \%$ injury 2 WAA with fenoxaprop-p-ethyl/safener applied LPOST at the $1 \mathrm{X}$ and $2 \mathrm{X}$ rate. Although mean injury was as high as $5 \%$, it would not be generally considered commercially significant to a grower. Moreover, the injury observed was transient and did not decrease grain yield.

For Exeter, winter wheat market class was significant only for crop height and yield (Table 3). Similar to Ridgetown sites, SWWW $(91 \mathrm{~cm})$ and HRWW $(90 \mathrm{~cm})$ heights were greater than SRWW $(77 \mathrm{~cm})$ and HWWW $(79 \mathrm{~cm})$. Moreover, SWWW and SRWW yields were greatest $\left(6.1\right.$ to $\left.6.2 \mathrm{t} \cdot \mathrm{ha}^{-1}\right)$, while HWWW and HRWW yields were only 5.5 and $5.6 \mathrm{t}^{\mathrm{h}} \mathrm{ha}^{-1}$, respectively. Unlike Ridgetown sites, no significant effect due to herbicide treatment was identified. Similarly, excellent tolerance to fenoxaprop-p-ethyl/safener, applied at $92 \mathrm{~g} \cdot \mathrm{ai} \cdot \mathrm{ha}^{-1}$, has been observed in durum wheat [Triticum turgidum subsp. durum (Desf.) Husn.], spring barley (Horduem vulgare L.) and spring wheat [16]. Reference [17] evaluated durum wheat sensitivity to various POST herbicides and found that injury of $3.4 \%$ to $4.9 \%$ and $1.9 \%$ to $8.0 \%$ was present 1 WAA when fenoxaprop-p-ethyl/safener was applied at a $1 \mathrm{X}$ and $2 \mathrm{X}$ rates, respectively. However, injury decreased to $1.9 \%$ to $3.0 \%$ and $4.7 \%$ to $4.9 \%$ by 4 WAA, respectively, and neither treatment reduced yield. Moreover, fenoxaprop-p-ethyl has also been reported safe for use on red clover (Trifolium pretense L.); a legume commonly underseeded in winter wheat crops to fix nitrogen [18]. In a related study, reference [19] assessed triticale ( $\times$ Triticosecale Wittm. ex A. Camus) tolerance to the Group 1 herbicide clodinafop-propargyl and found that it did not cause significant crop injury or reduce crop height, seed yield or biomass at $1 \mathrm{X}$ and $2 \mathrm{X}$ rates. Reference [20] evaluated tolerance of sixteen spring wheat cultivars to $3 \mathrm{X}$ applications of diclofop-methyl (Group 1 herbicide) and reported differential tolerance, however, they concluded that injury did not always reflect yield and thus should not be used to identify susceptible cultivars. Reference [21] reported up to $9 \%$ injury in winter wheat, whereas, reference [22] reported cultivar-specific tolerance; differences were minor and inconsistent relative to treatment with difenzoquat.

Table 2. Main effects and interaction for percent visible injury, height, moisture and yield of winter wheat market class treated with fenoxaprop-p-ethyl/safener at Ridgetown, Ontario, Canada, from 2012 to $2014^{\mathrm{a}}$.

\begin{tabular}{|c|c|c|c|c|c|c|c|c|c|c|}
\hline \multirow{2}{*}{ Main effects } & & \multicolumn{4}{|c|}{ Injury (\%) } & \multirow{2}{*}{\multicolumn{2}{|c|}{$\begin{array}{c}\text { Height } \\
\text { (cm) }\end{array}$}} & \multirow{2}{*}{$\begin{array}{c}\text { Moisture } \\
(\%)\end{array}$} & \multirow{2}{*}{\multicolumn{2}{|c|}{$\begin{array}{c}\text { Yield } \\
\left(\mathrm{t} \cdot \mathrm{ha}^{-1}\right)\end{array}$}} \\
\hline & & \multicolumn{2}{|c|}{1 WAA } & \multicolumn{2}{|c|}{2 WAA } & & & & & \\
\hline Market class & & & & & & \multicolumn{2}{|c|}{$* *$} & NS & \multicolumn{2}{|c|}{$* *$} \\
\hline Soft white & & \multicolumn{2}{|c|}{3} & \multicolumn{2}{|c|}{1} & 95 & $\mathrm{a}$ & 16.9 & 6.4 & $\mathrm{~b}$ \\
\hline Soft red & & \multicolumn{2}{|c|}{3} & \multicolumn{2}{|c|}{1} & 76 & $\mathrm{~b}$ & 16.6 & 7.1 & $\mathrm{a}$ \\
\hline Hard white & & \multicolumn{2}{|c|}{3} & \multicolumn{2}{|c|}{1} & 76 & $\mathrm{~b}$ & 16.6 & 5.8 & c \\
\hline Hard red & & \multicolumn{2}{|c|}{2} & \multicolumn{2}{|c|}{1} & 93 & $\mathrm{a}$ & 16.8 & 6.2 & $\mathrm{~b}$ \\
\hline Fenoxaprop-p-ethyl treatment & Rate $\left(\right.$ g a.i. $\left.h a^{-1}\right)$ & \multicolumn{2}{|c|}{$*$} & \multicolumn{2}{|c|}{ * } & \multicolumn{2}{|c|}{ NS } & NS & \multicolumn{2}{|c|}{ NS } \\
\hline Nontreated control & & 0 & $\mathrm{a}$ & 0 & $\mathrm{a}$ & \multicolumn{2}{|c|}{87} & 16.8 & \multicolumn{2}{|c|}{6.4} \\
\hline EPOST & 92 & 0 & $\mathrm{a}$ & 1 & $\mathrm{a}$ & \multicolumn{2}{|c|}{85} & 16.7 & \multicolumn{2}{|c|}{6.3} \\
\hline EPOST & 184 & 1 & $\mathrm{ab}$ & 1 & $\mathrm{a}$ & \multicolumn{2}{|c|}{85} & 16.7 & \multicolumn{2}{|c|}{6.4} \\
\hline LPOST & 92 & 4 & bc & 1 & $\mathrm{ab}$ & \multicolumn{2}{|c|}{85} & 16.9 & \multicolumn{2}{|c|}{6.4} \\
\hline LPOST & 184 & 5 & c & 1 & b & \multicolumn{2}{|c|}{85} & 16.7 & \multicolumn{2}{|c|}{6.5} \\
\hline
\end{tabular}

aAbbreviations: EPOST, early post emergence; LPOST, late post emergence; WAA, weeks after herbicide application. 
Table 3. Main effects and interaction for percent visible injury, height, moisture and yield of winter wheat market class treated with fenoxaprop-p-ethyl at Exeter, Ontario, Canada, from 2012 to $2014^{\mathrm{a}}$.

\begin{tabular}{|c|c|c|c|c|c|c|c|c|}
\hline \multirow{2}{*}{ Main effects } & & \multicolumn{2}{|c|}{ Injury } & \multirow{2}{*}{\multicolumn{2}{|c|}{$\begin{array}{c}\text { Height } \\
(\mathrm{cm})\end{array}$}} & \multirow{2}{*}{$\begin{array}{c}\text { Moisture } \\
(\%)\end{array}$} & \multirow{2}{*}{\multicolumn{2}{|c|}{$\begin{array}{c}\text { Yield } \\
\left(\mathrm{t} \cdot \mathrm{ha}^{-1}\right)\end{array}$}} \\
\hline & & \multirow{2}{*}{$\frac{1 \text { WAA }}{\text { NS }}$} & \multirow{2}{*}{$\frac{2 \text { WAA }}{\text { NS }}$} & & & & & \\
\hline Market class & & & & & & NS & & \\
\hline Soft white & & 2 & 1 & 91 & $\mathrm{a}$ & 13.8 & 6.2 & $\mathrm{a}$ \\
\hline Soft red & & 2 & 1 & 77 & $\mathrm{~b}$ & 13.3 & 6.1 & $\mathrm{a}$ \\
\hline Hard white & & 2 & 1 & 79 & $\mathrm{~b}$ & 12.9 & 5.5 & $\mathrm{~b}$ \\
\hline Hard red & & 1 & 1 & 90 & $\mathrm{a}$ & 13.6 & 5.6 & $\mathrm{~b}$ \\
\hline Fenoxaprop-p-ethyl treatment & Rate $\left(g\right.$ a.i. $\left.\cdot h a^{-1}\right)$ & NS & NS & & & NS & & \\
\hline Nontreated control & & 0 & 0 & & & 13.8 & & \\
\hline EPOST & 92 & 1 & 1 & & & 13.5 & & \\
\hline EPOST & 184 & 2 & 1 & & & 13.4 & & \\
\hline LPOST & 92 & 1 & 0 & & & 13.4 & & \\
\hline LPOST & 184 & 2 & 2 & & & 13.4 & & \\
\hline
\end{tabular}

${ }^{\mathrm{a}}$ Abbreviations: EPOST, early post emergence; LPOST, late post emergence; WAA, weeks after herbicide application.

\section{Conclusion}

In summary, fenoxaprop-p-ethyl/safener applied POST at the manufacturers' proposed label dose can be safely used in SWWW, SRWW, HWWW and HRWW. Winter wheat tolerance to fenoxaprop-p-ethyl/safener was exceptional, showing injury of up to 5\% the LPOST application timing. Injury attributed to LPOST was transient and did not decrease yield. Despite the minor injury, no cultivar-specific sensitivity was observed. This research demonstrates that POST application of fenoxaprop-p-ethyl/safener should not cause commercially significant injury when applied under Ontario conditions. Future research should evaluate weed control potential of fenoxaprop-p-ethyl/safener.

\section{Acknowledgements}

The authors would like to acknowledge the technical support and assistance of Lynette Brown, Todd Cowan and Holly Byker. Funding for this research was provided by Grain Farmers of Ontario.

\section{References}

[1] Agriculture and Agri-Food Canada (2010) Crop Profile for Winter Wheat in Canada. http://publications.gc.ca/collections/collection_2012/agr/A118-10-29-2012-eng.pdf

[2] Kulasekera, K. (2014) Estimated Area, Yield, Production and Farm Value of Specified Field Crops, Ontario, 20112013. Ontario Ministry of Agriculture, Food and Rural Affairs, Guelph. http://www.omafra.gov.on.ca/english/stats/crops/estimate_new.htm

[3] Salmon, D. and McLelland, M. (2012) Winter Wheat in the Parkland Area of Alberta. http://www1.agric.gov.ab.ca/\$department/deptdocs.nsf/all/agdex94/\$file/112_11-1.pdf?OpenElement

[4] Entz, M.H., Fowler, D.B., Entz, M.H. and Fowler, D.B. (1991). Agronomic Performance of Winter versus Spring Wheat. Agronomy Journal, 83, 527-532. http://dx.doi.org/10.2134/agronj1991.00021962008300030002x

[5] Sikkema, P.H., Brown, L., Shropshire, C. and Soltani, N. (2007) Responses of Three Types of Winter Wheat (Triticum aestivum L.) to Spring-Applied Post-Emergence Herbicides. CropProtection, 5, 715-720. http://dx.doi.org/10.1016/j.cropro.2006.06.010

[6] Kong, L. et al. (2009) Differential Responses of Two Types of Winter Wheat (Triticum aestivum L.) to Autumn- and Spring-Applied Mesosulfuron-Methyl. Crop Protection, 28, 387-392. http://dx.doi.org/10.1016/j.cropro.2008.12.008

[7] Schroeder, J. and Banks, P.A. (1989) Soft Red Winter Wheat (Triticum aestivum) Response to Dicamba and Dicamba plus 2, 4-D. Weed Technology, 3, 67-71.

[8] Rinella, J.M., Kells, J.J. and Ward, R.W. (2001) Response of "Wakefield” Winter Wheat (Triticum aestivum) to Dicamba. Weed Technology, 15, 523-529. http://dx.doi.org/10.1614/0890-037X(2001)015[0523:ROWWWT]2.0.CO;2

[9] Mallory-Smith, C.A. and Retzinger, E.J. (2003) Revised Classification of Herbicides by Site of Action for Weed Resistance Management Strategies. Weed Technology, 17, 605-619. 
http://dx.doi.org/10.1614/0890-037X(2003)017[0605:RCOHBS]2.0.CO;2

[10] Incledon B.J. and Hall J.C. (1997) Acetyl-Coenzyme a Carboxylase: Quaternary Structure and Inhibition by Graminicidal Herbicides. Pesticide Biochemisty and Physiology, 57, 255-271. http://dx.doi.org/10.1006/pest.1997.2279

[11] Gronwald, J.W. (1991) Lipid Biosynthesis Inhibitors. Weed Science, 39, 435-449.

[12] Ontario Ministry of Agriculture, Food and Rural Affairs (OMAFRA) (2013) Guide to Weed Control 2014-2015: Publication 75. Queen's Printer for Ontario, Toronto.

[13] Cataneo, A.C., Ferreira, L.C., Mischan, M.M., Velini, E.D., Corniani, N.V. and Cerdeira, A.L. (2013) Mefenpyr-Diethyl Action on Fenoxaprop-p-Ethyl Detoxification in Wheat Varieties. Planta Daninha, 31, 387-393. http://dx.doi.org/10.1590/S0100-83582013000200016

[14] Hacker, E. Bieringer, H., Willms, L., Rösch, W., Köcher, H. and Wolf, R. (2000) Mefenpyr-Diethyl: A Safener for Fenoxaprop-p-Ethyl and Iodosulfuron in Cereals. Zeitschrift für Pflanzenkrankheiten und Pflanzenschutz, 439-500.

[15] Ontario Ministry of Agriculture, Food and Rural Affairs (OMAFRA) (2009) Agronomy Guide for Field Crops: Publication 811. Queen's Printer for Ontario, Toronto.

[16] Xie, H.S., Quick, W.A. and Hsiao, A.I. (1994) Spring Cereal Response to Imazamethabenz and Fenoxaprop-p-Ethyl as Influenced by Environment. Weed Technology, 8, 713-716.

[17] Soltani, N., Shropshire, C. and Sikkema, P.H. (2011) Sensitivity of Durum Wheat (Triticum turgidum) to Various Postemergence Herbicides. Agricultural Sciences, 2, 451-456.

[18] Robinson, M.A., Letarte, J., Cowbrough, M.J., Sikkema, P.H. and Tardif, F.J. (2014) Response of Underseeded Red Clover (Trifolium pratense L.) to Winter Wheat (Triticum aestivum L.) Herbicides as Affected by Application Timing. Agricultural Sciences, 5, 1351-1360.

[19] Raatz, L., Hills, M., McKenzie, R., Yang, R-C., Topinka, K. and Hall, L. (2011) Tolerance of Spring Triticale (× Triticosecale wittmack) to Four Wheat Herbicides. Weed Technology, 25, 84-89. http://dx.doi.org/10.1614/WT-D-10-00048.1

[20] Lemerle, D., Leys, A.R., Hinkley, R.B., Fisher, J.A. and Cullis, B. (1985) Tolerances of Wheat Cultivars to PostEmergence Wild Oat Herbicides. Animal Production Science, 25, 677-682. http://dx.doi.org/10.1071/EA9850677

[21] Shaw, D.R. and Wesley, M.T. (1991) Wheat (Triticum aestivum) Cultivar Tolerance and Italian Ryegrass (Lolium multiflorum) Control with Diclofop, BAY SMY 1500, and Metribuzin. Weed Technology, 5, 776-781.

[22] Tottman, D.R., Lupton, F.G.H., Oliver, R.H. and Preston, S.R. (1982) Tolerance of Several Wild Oat Herbicides by a Range of Winter Wheat Varieties. Annals of Applied Biology, 100, 365-373. 
Scientific Research Publishing (SCIRP) is one of the largest Open Access journal publishers. It is currently publishing more than 200 open access, online, peer-reviewed journals covering a wide range of academic disciplines. SCIRP serves the worldwide academic communities and contributes to the progress and application of science with its publication.

Other selected journals from SCIRP are listed as below. Submit your manuscript to us via either submit@scirp.org or Online Submission Portal.
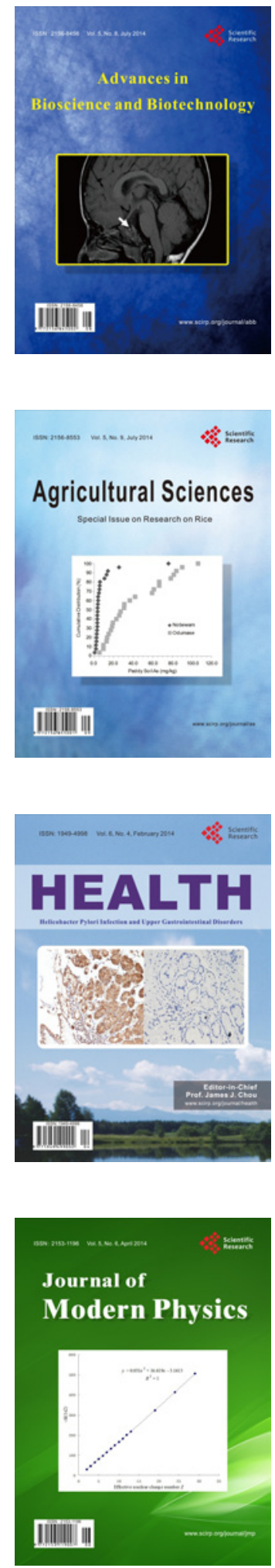
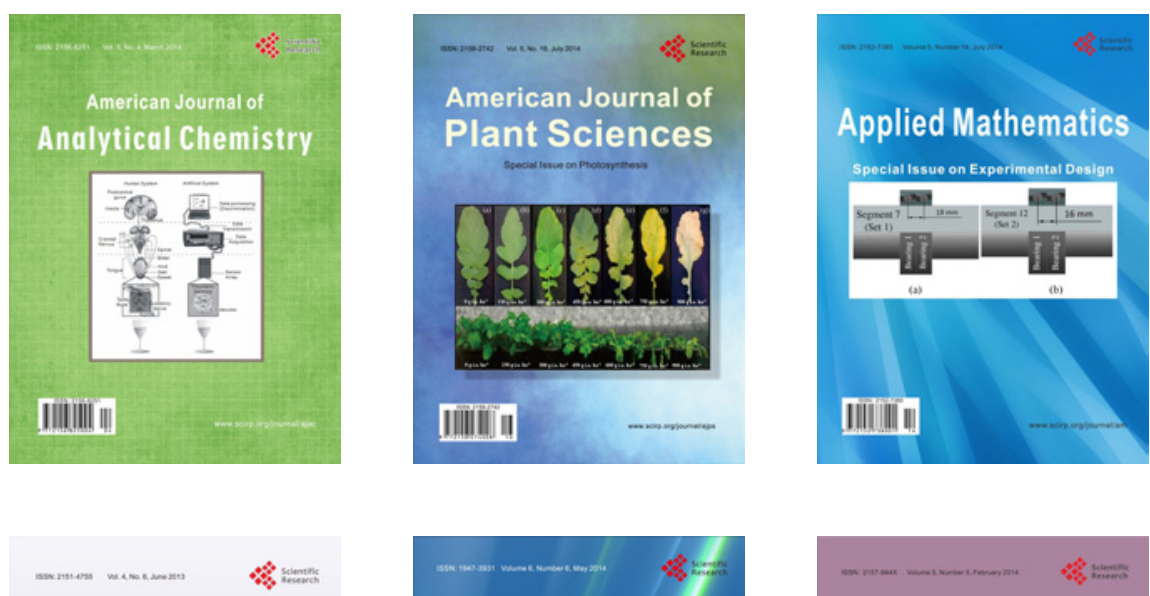

Creative Education
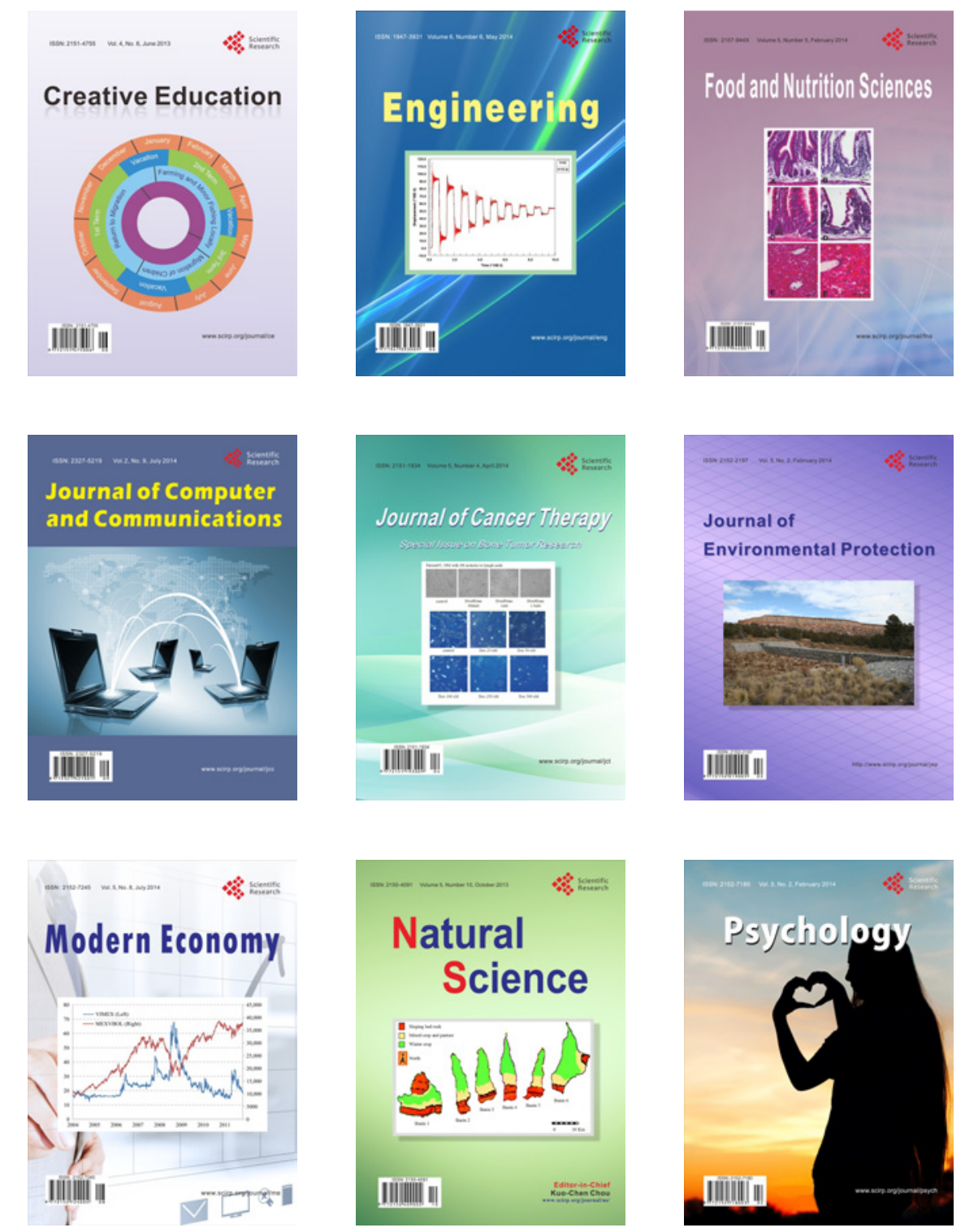